\title{
PERAN LEMBAGA PENDIDIKAN DALAM PENINGKATAN KUALITAS GURU PENDIDIKAN ANAK USIA DINI
}

\author{
${ }^{1)}$ Umu Da'watul Choiro, email : ummudawatulchoiroh@stitmatuban.ac.id \\ ${ }^{2)}$ Agus Fathoni Prasetyo, email : agusfathoni@stitmatuban.ac.id
}

\begin{abstract}
The big problem that is still faced by national education until now is the issue of quality, effectiveness and efficiency of education. It has become a common understanding that the issue of educators is far more important than the problems of curriculum and other educational components. With the following important aspects educational institutions can play a role in improving the quality of their educators, including: (1) salaries and welfare standards that are appropriate for their lives, (2) qualification standards, (3) competency standards and efforts to improve them, (4) certification system for educators and educators and professional transfers that do not meet competency standards, (4) honest and transparent selection / recruitment, (5) career development standards, (6) preparation of prospective educators and education personnel in line with competency standards, and more emphasizing practice and with strong theory, (7) education and training system in professional training and education institutions and (8) empowering professional development organizations.
\end{abstract}

Keywords: educational institutions, quality, educators

\section{Pendahuluan}

Pendidikan menjadi salah satu kebutuhan manusia yang tidak dapat digantikan, maksudnya setiap manusia dapat dipastikan membutuhkan pelayanan pendidikan dalam memenuhi kebutuhan hidupnya. Pemerintah mengatur hal sedemikian rupa, baik undang-undang maupun kebijakan-kebijakan agar setiap individu mendapatkan hak akan pendidikan. Masalah besar yang masih dihadapi oleh pendidikan nasional hingga saat ini adalah persoalan mutu, efektivitas dan efisiensi pendidikan. Masalah-masalah ini menimbulkan kegundahan pada masyarakat yang kerap dihadirkan dalam diskusi, seminar dan kegiatan lainnya. Keresahan bahwa pendidikan saat ini masih rendah mutunya, menjadikan pendidik yang memegang kunci dalam pembelajaran perlu untuk mendapatkan perhatian dari lembaga yang menaunginya. Karena suksesnya pendidikan yang juga berarti suksesnya pembangunan bangsa dan negara kita.

Undang-undang Nomor 20 Tahun 2003 tentang Sistem Pendidikan Nasional menjelaskan bahwa "pendidikan adalah usaha sadar dan terencana untuk mewujudkan suasana belajar dan proses pembelajaran agar peserta didik secara aktif mengembangkan potensi dirinya untuk 
memiliki kekuatan spiritual keagamaan, pengendalian diri, kepribadian, kecerdasan, akhlak mulia, serta keterampilan yang diperlukan dirinya, masyarakat, bangsa dan Negara". ${ }^{1}$ Hal ini menunjukkan bahwa pendidikan bukan hanya sekedar penyampaian pengetahuan secara kognisi saja, tetapi juga mengharapkan perubahan pada keterampilan, moral dan spiritual peserta didik.

Telah menjadi pemahaman umum bahwa masalah pendidik jauh lebih penting daripada masalah kurikulum dan komponen pendidikan lain. Hal ini memberikan gambaran bahwa masalah pendidik atau guru memang belum sepenuhnya mendapatkan perhatian yang memadai oleh para praktisi pendidikan, apalagi oleh pengambil kebijakan pendidikan. Pendidik menjadi seorang figur sentral dalam proses pembelajaran. Pendidik memegang fungsi peranan penting dan merupakan komponen yang paling menentukan dalam sistem pendidikan secara keseluruhan. Dalam hal ini, lembaga pendidikan memiliki andil untuk turut berperan dalam upaya peningkatan kualitas pendidik.

\section{Kajian Teori}

Simanjuntak mendefinisikan pelatihan merupakan bagian dari investasi SDM (human investment) untuk meningkatkan kemampuan dan keterampilan kerja sehingga meningkatkan kinerja pegawai ${ }^{2}$. Pelatihan biasanya dilakukan dengan kurikulum yang disesuaikan dengan kebutuhan jabatan, diberikan dalam waktu yang relatif pendek, untuk membekali seseorang dengan keterampilan kerja. Dapat disimpulkan bahwa pelatihan merupakan suatu kegiatan dalam maksud untuk memperbaiki dan mengembangkan sikap, tingkah laku, keterampilan, dan pengetahuan dari para pegawai sesuai dengan keinginan dari suatu lembaga atau lembaga kursus dan pelatihan.

\section{Metode}

Penelitian ini menggunakan pendekatan kualitatif dengan desain studi kasus. Penelitian dilaksanakan di RA Husnul Aulad Klotok, Plumpang, Tuban. Penelitian dilakukan dengan menggali informasi mengenai tentang peran lembaga pendidikan dalam peningkatan kualitas pendidik anak usia dini melalui pendidikan dan pelatihan di RA Husnul Aulad Klotok,

${ }^{1}$ Undang-Undang Republik Indonesia Nomor 20 Tahun 2003 tentang Sistem Pendidikan Nasional. 2003. Bandung: Citra Umbara.

${ }^{2}$ Payaman J Simanjuntak,Manajemen dan Evaluasi Kinerja, Jakarta: FE UI, 2005, hal: 5. 
Plumpang, Tuban. Pengumpulan data menggunakan observasi dan wawancara. Untuk menjamin keabsahan data, digunakan pengujian konfirmabilitas atau uji objektivitas penelitian. Uji konfirmabilitas dilakukan setelah melaksanakan observasi, yakni dengan melakukan wawancara. Dari hasil pengamatan yang telah dilakukan, kemudian dilakukan konfirmasi kepada kepala lembaga dan kepada guru untuk menguji apakah informasi yang didapatkan benar adanya menurut narasumber.

\section{Hasil dan Pembahasan}

Setiap lembaga pendidikan pasti memiliki visi misi dalam rangka mengembangkan pendidikan. Pendidik sebagai tenaga pelaksanaan tugas dan tanggung jawab dituntut untuk sedapat mungkin bertindak sebagai agen pembelajaran yang profesional. Negarapun telah mengatur dalam undang-undang untuk memahami tugas dan tanggung jawab tenaga pendidik dalam hal ini seorang guru, pada Undang-undang nomor 20 Tahun 2003 dan Undang-undang RI Nomor 14 tahun 2005 tentang Guru dan Dosen serta Peraturan Pemerintah RI Nomor 19 Tahun 2005 tentang Standar Nasional Pendidikan.

Keberadaan pendidik sangat diharapkan memberikan pembelajaran didasarkan pada kompetensi yang harus dimiliki, sesuai dengan tuntutan perkembangan jiwa peserta didik. Penguasaan kompetensi pendidik sebagai agen pembelajaran yang meliputi kompetensi paedagogik/andragogik, kompetensi kepribadian, kompetensi sosial dan kompetensi profesional

yang dapat dibuktikan melalui proses pencapaian mutu pendidikan berdasarkan kriteria ketuntasan minimal.

Upaya peningkatan mutu pendidikan dipengaruhi oleh berbagai macam faktor. Faktor yang satu saling berpengaruh terhadap faktor yang lainnya. Namun demikian, faktor yang paling penting adalah pendidik, karena hitam-putihnya proses belajar mengajar di dalam kelas banyak dipengaruhi oleh kualitas pendidiknya. Sikap dan tingkah laku, penampilan profesional, kemampuan individual, dan apa saja yang melekat pada pribadi sang pendidik, akan diterima oleh peserta didiknya sebagai rambu-rambu untuk diteladani atau dijadikan bahan pembelajaran. Bagi sebagian besar orangtua siswa, sosok pendidik masih dipandang sebagai wakil orangtua ketika anak-anaknya tidak berada di dalam keluarga.

Di era teknologi informasi, pendidik memang tidak lagi dapat berperan sebagai satusatunya sumber ilmu pengetahuan. Peran pendidik telah berubah lebih menjadi fasilitator, 
moderator dan motivator bagi peserta didik. Dalam era teknologi informasi sepert saat ini peserta didik dengan mudah dapat mengakses informasi apa saja yang tersedia melalui internet. Dalam kondisi seperti itu, maka pendidik diharapkan dapat memberikan peran yang lebih besar untuk memberikan rambu-rambu etika dan moral dalam memilih informasi yang diperlukan. Hal tersebut dapat disimpulkan bahwa peran pendidik tidak dapat digantikan. Untuk dapat melaksanakan peran tersebut secara efektif dalam proses pendidikan, pendidik dan tenaga kependidikan harus ditingkatkan mutunya dengan skenario yang jelas.

Sosok pimpinan lembaga selaku penanggung jawab pengelolaan administrasi dan teknis pembelajaran diharapkan mampu bertindak selaku manager dalam upaya menumbuhkembangkan kompetensi pendidik lewat pemberdayaan melalui bentuk penghargaan seperti pemberian kesempatan pendidikan dan latihan profesi, tunjangan profesi, penyediaan sarana pendukung pembelajaran, pemerataan jam pembelajaran, pemberian insentif berdasarkan tugas dan tanggung jawabnya serta jaminan kenyamanan dan keamanan dalam menjalankan tugas.

Salah satu upaya yang dapat dilakukan oleh lembaga dalam rangka peningkatan kualitas pendidiknya adalah melalui optimalisasi peran pimpianan lembaganya terlebih dahulu. Anwar mengemukakan bahwa "kepala sekolah (pimpinan lembaga) sebagai pengelola memiliki tugas mengembangkan kinerja personel, terutama meningkatkan kompetensi profesional guru"3. Yang dimaksud dengan kompetensi profesional di sini, tidak hanya berkaitan dengan penguasaan materi semata, tetapi mencakup seluruh jenis dan isi kandungan kompetensi. Terdapat tujuh peran utama pemimpin lembaga yaitu, sebagai: (1) educator (pendidik); (2) manajer; (3) administrator; (4) supervisor (penyelia); (5) leader (pemimpin); (6) inovator; dan (7) motivator. ${ }^{4}$

Sebagai edukator, pimpinan lembaga harus memiliki strategi yang tepat untuk meningkatkan profesionalisme tenaga kependidikan di sekolahnya. Iklim lembaga pendidikan yang kondusif, memberikan nasehat kepada anggota lembaga, memberikan dorongan kepada tenaga kependidikan serta melaksanakan model pembelajaran yang menarik, seperti team teaching sangat diperlukan dalam upaya peningkatan kualitas pendidik yang ada pada lembaga.

${ }^{3}$ Idochi Anwar dan Yayat Hidayat Amir, Administrasi Pendidikan, Teori, Konsep dan Isu. Bandung, Universitas Pendidikan Indonesia, 2000, hal: 23.

${ }^{4}$ Depdiknas Dirjen Pendidikan Dasar dan Menengah, Rambu-rambu Penilaian Kinerja Institusi Pendidikan (SLTP dan SMU), Jakarta: Rineka Cipta, 2000, hal: iv. 
Lembaga pendidikan melalui pimpinannya perlu selalu berupaya meningkatkan kualitas pembelajaran yang dilakukan oleh para pendidik. Pimpinan lembaga dapat mendeegasikan para pendidik dalam pelatihan untuk menambah wawasannya; memberikan kesempatan kepada para pendidik untuk meningkatkan pengetahuan dan keterampilannya dengan belajar ke jenjang pendidikan yang lebih tinggi. Selain itu penggunaan waktu belajar secara efektif dengan cara mendorong para pendidik untuk memulai dan mengakhiri pembelajaran sesuai waktu yang ditentukan dapat dilakukan oleh lembaga pendidikan.

Perlunya strategi yang tepat bagi lembaga pendidikan untuk memberdayakan tenaga pendidik melalui persaingan yang dapat memunculkan kerja sama dan memberikan kesempatan kepada pendidik untuk meningkatkan profesinya, serta mendorong keterlibatannya dalam berbagai kegiatan yang menunjang program lembaga pendidikan. Pimpinan lembaga selaku manajer harus mampu menghadapi berbagai persoalan di lembaga pendidikan, berpikir secara analitik, konseptual, dan berusaha menjadi hakim yang adil dalam memecahkan berbagai masalah, dan mengambil keputusan yang memuaskan stakeholders dari lembaga pendidikan tersebut.

Lembaga pendidikan perlu untuk memberikan peluang kepada pendidik untuk meningkatkan profesinya. Selain itu perlunya untuk mendorong keterlibatan seluruh tenaga pendidik dalam setiap kegiatan (partisipatif). Dalam hal ini pimpinan lembaga berpedoman pada asas tujuan, asas keunggulan, asas mufakat, asas kesatuan, asas persatuan, asas empirisme, asas keakraban, dan asas integritas.

Inovasi lembaga pendidikan juga mempengaruhi peningkatan kualitas dari pendidik. Pimpinan lembaga perlu memiliki strategi yang tepat untuk menjalin hubungan yang harmonis dengan lingkungan, mencari gagasan baru, mengintegrasikan setiap kegiatan, memberikan teladan kepada tenaga pendidik dan mengembangkan model-model pembelajaran yang inovatif. Inovasi dalam meningkatkan profesionalisme tenaga pendidik akan tercermin dari caranya melakukan pekerjaan secara konstruktif, kreatif, integratif, rasional, obyektif, disiplin, fleksibel dan tentunya menyenagkan bagi para peserta didiknya.

Penting pula bagi lembaga pendidikan untuk memiliki strategi yang tepat dalam memberikan motivasi kepada para tenaga pendidik dalam melakukan berbagai tugas dan fungsinya. Motivasi ini dapat ditumbuhkan melalui pengaturan lingkungan fisik, suasana kerja, disiplin, dorongan, penghargaan secara efektif dan penyediaan berbagai sumber belajar melalui 
pengembangan pusat sumber belajar. Dorongan dan penghargaan merupakan dua sumber motivasi yang efektif diterapkan oleh lembaga pendidikan. Motivasi dapat dikatan sebagai penggerak aga tenaga pendidik yang ada dalam lembaga pendidikan terus mengembangkan dirinya, menjadi seorang pendidik yang berkualitas.

Untuk meningkatkan kualitas dan kuantitas kegiatan belajar mengajar yang dilakukan oleh pendidik, maka profesi pendidik harus memiliki dan menguasai perencanaan kegiatan belajar mengajar, melaksanakan kegiatan yang direncanakan dan melakukan penilaian terhadap hasil dari proses belajar mengajar. Kemampuan pendidik dalam merencanakan dan melaksanakan proses pembelajaran merupakan faktor utama dalam mencapai tujuan pengajaran. Keterampilan merencanakan dan melaksanakan proses belajar mengajar ini sesuatu yang erat kaitannya dengan tugas dan tanggung jawab pendidik sebagai pengajar yang mendidik.

Pendidik mengandung arti yang sangat luas, tidak sebatas memberikan bahan-bahan pengajaran tetapi menjangkau etika dan estetika perilaku dalam menghadapi tantangan kehidupan di masyarakat. Sebagai pengajar, pendidik hendaknya memiliki perencanaan pengajaran yang cukup matang. Perencanaan pengajaran tersebut erat kaitannya dengan berbagai unsur seperti tujuan pengajaran, bahan pengajaran, kegiatan belajar, metode mengajar, dan evaluasi. Unsur-unsur tersebut merupakan bagian integral dari keseluruhan tanggung jawab guru dalam proses pembelajaran.

Secara umum terdapat beberapa langkah strategi yang dapat diimplementasikan dalam lingkungan pendidikan dengan tujuan bahwa peningkatan mutu pendidik dan tenaga kependidikan. Strategi yang dapat dilakukan oleh lembaga pendidikan dalam rangka peningkatan kualitas pendidik dapat dilakukan melalui self assessment. Self assessment atau evaluasi diri sebagai langkah awal bagi setiap lembaga pendidikan yang ingin, atau menerncanakan untuk meningkatkan kualitas sumber daya manusia. Self assessment dimulai dengan curah pendapat yang diikuti oleh seluruh warga yang ada di lembaga pendidikan tersebut, dan dapat pula diikuti oleh anggota komite (jika ada).

Tujuan dari kegiatan evaluasi ini adalah untuk mengetahui kondisi lembaga saat ini dalam segala aspeknya (seluruh komponen), kemajuan yang telah dicapai, maupun masalahmasalah yang dihadapi ataupun kelemahan yang dialami. Kegiatan evaluasi diri ini juga merupakan refleksi/mawas diri, untuk membangkitkan kesadaran/keprihatinan akan penting dan perlunya pendidikan yang bermutu, sehingga timbul komitmen bersama untuk meningkatkan 
mutu, serta merumuskan titik tolak bagi lembaga pendidikan yang ingin atau akan mengembangkan diri terutama dalam hal mutu.

\section{Penutup}

Dengan demikian dapat kita memahami realitas dilapangan memperlihatkan bahwa semakin besarnya harapan yang digantungkan masyarakat terhadap tugas guru dalam upaya meningkatkan kualitas pendidikan, senantiasa mengalami beberapa hambatan-hambatan, seperti halnya pemberdayaan kompetensi guru kurang memadai, lemahnya administrasi pembelajaran, Ilmu pengetahuan dan sarana pendukung pembelajaran serta dimana kultur masyarakat bertumpu pada konsep pembelajaran disekolah. Olehnya itu peran pemimpin selaku Kepala Sekolah sebagai supervaisor diharapkan menjadi sosok mengupayakan pemberian semangat atau motivasi bagi para guru agar senantiasa menjalankan tugas pembelajarannya dengan secara maksimal sebagaimana yang diamanatkan undang-undang.

Upaya peningkatan kualitas pendidik memang tidak dapat dilepaskan dari peran lembaga pendidikan di dalamnya. Dengan aspek-aspek penting sebagai berikut lembaga pendidikan dapat berperan dalam meningkatkan kualitas pendidik yang dimilikinya, meliputi: (1) gaji dan standar kesejahteraan yang layak untuk kehidupannya, (2) standar kualifikasi, (3) standar kompetensi dan upaya peningkatannya, (4) sistem sertifikasi pendidik dan tenaga kependiikan dan alih profesi yang tidak memenuhi standar kompetensi, (4) seleksi/rekruitmen

yang jujur dan transparan, (5) standar pembinaan karir, (6) penyiapan calon pendidik dan tenaga kependidikan yang selaras dengan standar kompetensi, dan lebih menekankan praktik dan dengan teori yang kuat, (7) sistem diklat di lembaga inservice training dan pendidikan profesi dan (8) pemberdayaan organisasi pembinaan profesional. 


\section{Referensi}

Anwar, Idochi dan Yayat Hidayat Amir. 2000. Administrasi Pendidikan, Teori, Konsep dan Isu. Bandung: Universitas Pendidikan Indonesia.

Departemen Pendidikan Nasional. 2000. Panduan Manajemen Sekolah, Proyek Peningkatan mutu Guru Kelas SD Setara D.II Jakarta.

Depdiknas Dirjen Pendidikan Dasar dan Menengah, Rambu-rambu Penilaian Kinerja Institusi Pendidikan (SLTP dan SMU). Jakarta: Rineka Cipta, 2000, hal. Iv

Engkoswara. 1987. Dasar-Dasar Administrasi Pendidikan. Jakarta: Depdikbud

Simanjuntak, Payaman J. 2005. Manajemen dan Evaluasi Kinerja. Jakarta: FE UI.

Undang-Undang Republik Indonesia Nomor 20 Tahun 2003 tentang Sistem Pendidikan Nasional. 2003. Bandung: Citra Umbara. 